\title{
The Effect of Brand Communication, Brand Experience, and Brand Image on Yamaha Brand Loyalty in West Jakarta: Brand Trust as a Mediation Variable
}

\author{
Ceri Hartono ${ }^{1}$, Rodhiah ${ }^{2}$ \\ ${ }^{1,2}$ Faculty of Economics and Business, Universitas Tarumanagara, Indonesia \\ ceri.115180189@stu.untar.ac.id,rodhiah@fe.untar.ac.id
}

\begin{abstract}
The purpose of this study was to empirically examine the effect of brand communication, brand experience, and brand image, brand trust on Yamaha Motor brand loyalty. The sampling technique used was the convenience sampling method, as many as 100 respondents who had used or owned a Yamaha Motorcycle in West Jakarta. Data collection by distributing online questionnaires using Google Forms. The analysis technique in this research is SEM using the SmartPLS 3.0 program. The results showed that brand communication and brand experience had a positive and significant effect on brand image, brand communication had a positive and insignificant effect on brand image, brand experience and brand image had a positive and significant influence on brand trust and brand loyalty, brand trust had a positive and significant effect positive and significant to brand loyalty.
\end{abstract}

\section{Keywords}

brand communication; brand experience; brand image; brand trust; brand loyalty

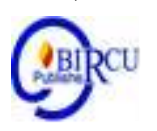

\section{Introduction}

The automotive industry has an important role in providing transportation in all distribution activities, the automotive industry also provides convenience in traveling with more effective and efficient time, cost and energy. The advantage of motorized transportation is that it can deliver faster, safer, more comfortable, and easier travel distances on land. The human need for traveling mobility is increasing so that it will automatically increase the need for transportation that has effectiveness and efficiency (Romdonah, Fathoni \& Haryono, 2015). The purpose of brand communication is to increase customer awareness and memory of the brand so that customers will buy a brand that they always remember which can increase customer satisfaction (Zehir et al., 2011). Because customer engagement is a psychological result of the experience when using a brand that motivates customers to form perceptions and influences engagement between customer behavior and the brand (Hussein, 2018).

Thus, Yamaha customers will be happy and feel comfortable so that brand communication and brand experience from Yamaha can be felt by customers who can add positive value to Yamaha's brand image in the community, taking into account consumer input and desires. Chinomona (2016), discusses brand communication, brand image and brand trust as antecedents of brand loyalty in the Gauteng Province of South Africa which resulted in a significant positive relationship. Winnie \& Keni's research (2020), produces a positive relationship by discussing the predictions of brand experience and perceived quality on brand loyalty Global Fashion Brands: Brand trust as a mediating variable. However, the research of Rahmat \& Marso (2020), has insignificant results on the brand experience variable on brand loyalty and brand image on brand loyalty in their research. Research from Pandean \& Budiono (2021), also produces a non-positive and insignificant 
relationship that discusses brand image and brand experience to predict McDonald's brand loyalty with brand trust as a mediating variable.

When the brand image has been achieved, a good brand trust is formed from customers which can then become Yamaha's brand loyalty. Brand trust represents an important role as a mediator in the relationship that brand experience has with brand loyalty (Khan et al., 2019 in Paredes et al., 2020). Without a positive and strong brand image, it will be difficult to attract new customers and retain repeat customers, consumer views and thoughts about a product can lead to trust in the brand and simultaneously lead to consumer loyalty (Rizan, 2012 in Masman et al., 2020). Thus, it is very important for businesses to find ways to earn and maintain brand loyalty by building consumer trust (Pratiwi et al., 2015). Trust is a key variable in maintaining long-term relationships to show consumer satisfaction with certain brands (Jhangir et al, 2009 in Pratiwi et al., 2015). Because the positive value of brand trust is the repetition of purchasing a given product because consumers already feel trust in the brand because of the quality of the product from the brand itself and create brand loyalty. The higher the value of trust in a brand, the more confident we will be to make a purchase on the product without any hesitation (Veronica \& Rodhiah, 2021).

\section{Review of Literature}

\subsection{Brand Communication}

Brand communication is the communication ability of a brand that gives positive results to voters so that it will lead to trust in a brand (Arenggoasih, 2016). Jones and Kim (2011) in Chinamona (2016) define "brand communication is when an idea or image of a product or service is marketed so that its distinctiveness is identified and recognized by many consumers". Based on this definition, it is known that brand communication is an activity to convey ideas, images, differentiation, and uniqueness possessed by a brand, so that it can influence consumer perceptions to choose a brand that has already been attached to the minds of consumers both now and in the future. communication is a way for companies to express their brands and products so that they are easily remembered by consumers.

\subsection{Brand Experience}

Experience is important for every consumer to get what they expect from something received or experienced. Brakus et al (2009) in Kusuma (2014), define brand experience as the sensations, feelings, cognitions and consumer responses evoked by the brand, related to the stimuli generated by the brand design, brand identity, marketing communications, people, and the environment the brand is marketed.

Marketing is a process of planning and execution, starting from the conception stage, pricing, promotion, to the distribution of goods, ideas and services, to make exchanges that satisfy the individual and his institutions (Dianto in Asmuni et al, 2020). According to Tjiptono in Marlizar (2020) marketing performance is a function that has the greatest contact with the external environment, even though the company only has limited control over the company's environment. In the world of marketing, consumers are assets that must be maintained and maintained their existence in order to remain consistent with the products we produce (Romdonny and Rosmadi, 2019).

Zehir et al (2011), explained that brand experience is conceptualized as subjective, internal consumer responses (feeling sensations, and cognitions) and behavioral responses evoked by brand-related stimuli that are part of brand design and identity, packaging, 
communication, and the environment. Westhuizen (2018), explains that brand experience is your thoughts about your favorite brand that are related to your feelings, thoughts, and experiences with that brand. Based on the above definition, it can be concluded that brand experience is a feeling experienced by consumers themselves towards a brand.

\subsection{Brand Image}

Salinas \& Pérez (2009) in Chinomona (2016), define brand image as a consumer's mental picture of an offer and it includes the symbolic meanings that consumers associate with specific attributes of a product or service. Pars \& Gulsel (2011) in witała et al., (2018) explain that brand image is an impression made as a consequence of many factors (for example, associations related to a particular brand name, purchase experience, reputation of a particular company, advertising form and size, promotions, etc.). Sasmita \& Suki (2015) explain that a familiar brand image in the eyes of consumers can help companies to host new brands and increase sales of current brands. Based on the above definition, it can be concluded that brand image is the consumer's view of the brand, good or bad in society.

\subsection{Brand Trust}

Brand trust can be defined as the extent to which a consumer believes that a particular brand he has confidence in fulfilling his desires (Zhou et al., 2011) in Chinomona (2016). Customer trust in the brand (brand trust) is defined as the customer's desire to rely on a brand with the risks faced because expectations of the brand will lead to positive results (Lau \& Lee, (1999, p. 344) in Rizan, (2012)). Brand trust is the willingness of consumers to rely on the brand and its promises which are considered an important antecedent of brand loyalty (Dia et al., (2012) in Atulkar, (2020)). Based on the above definition, it can be concluded that brand trust is a consumer's feeling towards a brand that the product is good for long-term use.

\subsection{Brand Loyalty}

Pappu \& Quester, (2016) in Atulkar, (2020) conclude that brand loyalty is a measure of the attachment that customers have to a brand, motivating customers to show consistent buying behavior from the preferred brand. Brand loyalty is repurchase behavior that reflects decision awareness when consumers continue to buy the same brand (Solomon, (2011: 646) in Bilgin, (2018)). Ebrahim, (2020) explains that brand loyalty is a psychological tendency including attitudes, preferences, and commitment to the brand, not merely the perspective of purchasing actions taken against the brand. Based on the above definition, it can be concluded that brand loyalty is a commitment made by consumers to consume products from that brand repeatedly.

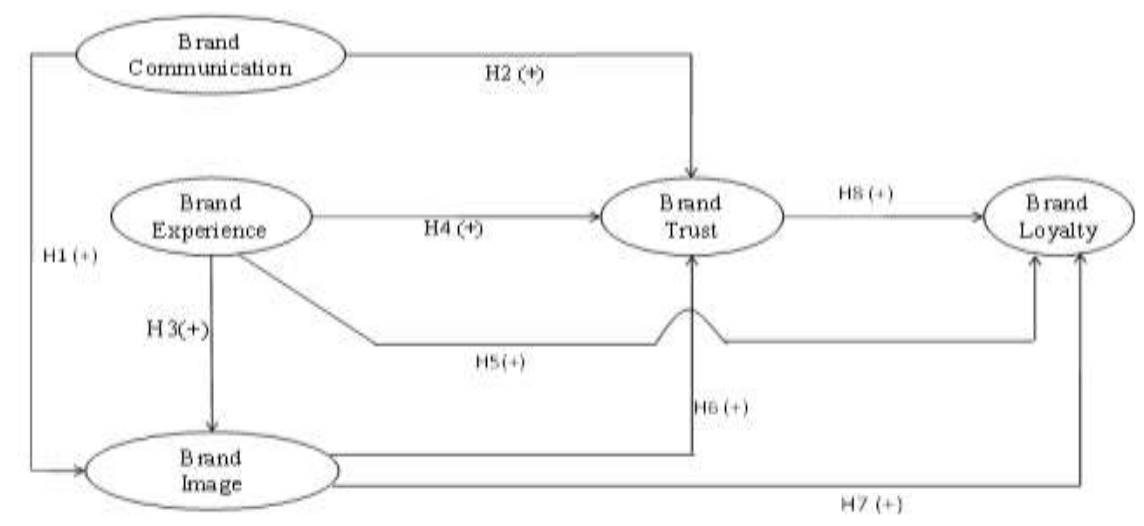

Figure 1. Research Model 
The research hypothesis is as follows:

Hypothesis 1: Brand communication has a positive and significant effect on brand experience.

Hypothesis 2: Brand communication has a positive and significant effect on brand trust. Hypothesis 3: Brand experience has a positive and significant influence on brand image. Hypothesis 4: Brand experience has a positive and significant effect on brand trust. Hypothesis 5: Brand experience has a positive and significant effect on brand loyalty. Hypothesis 6: Brand image has a positive and significant effect on brand trust. Hypothesis 7: Brand image has a positive and significant effect on brand loyalty. Hypothesis 8: Brand trust has a positive and significant effect on brand loyalty. Hypothesis 9: Brand trust can mediate brand communication, brand experience, and brand image on brand loyalty.

\section{Research Method}

The research population is Yamaha motorcycle users who live in West Jakarta. The sample collection technique that the researcher uses is convenience sampling, with the reason that there are respondent criteria. The number of samples studied were 100 respondents. Data collection techniques using a questionnaire. Questionnaires were distributed online using Google Forms to respondents who use Yamaha motorcycles in West Jakarta. In this study, the variables studied included: brand communication (X1), brand experience (X2), and brand image (X3) being the independent variable, then brand loyalty became the dependent variable, then brand trust became the mediating variable. Research data processing using PLS-SEM software which consists of two analyzes, namely the outer model and the inner model.

\section{Results and Discussion}

\subsection{Results}

\section{Respondent Profile}

Based on the data on the gender characteristics of the respondents, the majority of respondents were male $(66 \%)$ with a range of $17-22$ years $(72 \%)$, had the latest education in SMA (High School) (62\%), and worked as a student. (62\%).

\section{a. Outer Model}

Based on the analysis of the results of the measurement model (Outer Model Analysis) it was found that all indicators used to measure the research variables were valid and reliable so that they could represent the research variables and were trustworthy and reliable.

1. Convergent Validity

Table 1. AVE Score Result

\begin{tabular}{|l|c|}
\hline \multicolumn{1}{|c|}{ Variable / Dimention } & Average Variance Extracted \\
\hline Brand Communication & 0.634 \\
\hline Brand Experience & 0.640 \\
\hline Brand Image & 0.668 \\
\hline Brand Trust & 0.724 \\
\hline Brand Loyalty & 0.817 \\
\hline
\end{tabular}


It is known that the AVE value of each variable has a value above 0.5 which has met the criteria of convergent validity as measured by the AVE value. This indicates that the variables in this study have met the criteria.

\section{Discriminant Validity}

Table 2. Cross Loading Analysis Results

\begin{tabular}{|l|c|l|l|l|}
\hline Variable & $\begin{array}{l}\text { Brand } \\
\text { Communication }\end{array}$ & $\begin{array}{l}\text { Brand } \\
\text { Experience }\end{array}$ & $\begin{array}{l}\text { Brand } \\
\text { Image }\end{array}$ & $\begin{array}{l}\text { Brand } \\
\text { Loyalty }\end{array}$ \\
\hline Brand Experience & 0.692 & & & \\
\hline Brand Image & 0.773 & 0.884 & & \\
\hline Brand Loyalty & 0.587 & 0.818 & 0.848 & \\
\hline Brand Trust & 0.638 & 0.801 & 0.885 & 0.834 \\
\hline
\end{tabular}

It is known that the loadings value of each indicator of each variable is greater than the value of loadings other variables. This shows that these indicators have meet the discriminant validity criteria as measured by the value of cross loadings.

\section{Composite Reliability}

Table 3. Reliability Analysis Results

\begin{tabular}{|c|c|c|c|c|c|c|c|c|c|}
\hline \multicolumn{2}{|c|}{$\begin{array}{c}\text { Brand } \\
\text { Communication }\end{array}$} & \multicolumn{2}{c|}{$\begin{array}{c}\text { Brand } \\
\text { Experience }\end{array}$} & \multicolumn{2}{c|}{ Brand Loyalty } & \multicolumn{2}{c|}{ Brand Image } & \multicolumn{2}{c|}{ Brand Trust } \\
\hline YC3 & 0.751 & YE2 & 0.872 & YL1 & 0.796 & YM3 & 0.789 & YT1 & 0.912 \\
\hline YC5 & 0.722 & YE3 & 0.829 & YL2 & 0.785 & YM4 & 0.805 & YT5 & 0.895 \\
\hline YC6 & 0.831 & YE5 & 0.850 & YL3 & 0.856 & YM5 & 0.837 & - & - \\
\hline YC7 & 0.873 & - & - & YL5 & 0.830 & YM6 & 0.767 & - & - \\
\hline
\end{tabular}

\begin{tabular}{|c|c|}
\hline Variable & Composite Reability \\
\hline Brand Communication & 0.873 \\
\hline Brand Experience & 0.887 \\
\hline Brand Image & 0.877 \\
\hline Brand Loyalty & 0.889 \\
\hline Brand Trust & 0.899 \\
\hline
\end{tabular}

Composite reliability of all variables is above 0.6 and all indicators have loading factor above 0.4. it can be concluded that the variables used in this study is reliable.

\section{b. Inner Model}

1. Coefficient of Determination Test (R2)

There is an r-square value of 0.536 which explains that $53.6 \%$ of the brand trust variable can be explained by the brand communication, brand experience, and brand image variables. The remaining $46.4 \%$ can be explained by variables not examined in this study. There is an r-square value of 0.588 which explains that $58.8 \%$ of the brand image variable can be explained by the brand communication and brand experience variables. The remaining $41.2 \%$ can be explained by variables not examined in this study. There is an $r-$ square value of 0.586 which explains that $58.6 \%$ of the brand loyalty variable can be 
explained by the brand trust, brand experience, and brand image variables. The remaining $41.4 \%$ can be explained by variables not examined in this study. It is concluded that the value of the determinant coefficient in this study has varying levels because each variable has a value between 0.53 and 0.58 . So it can be said that all exogenous variables have a moderate effect on endogenous variables.

Table 4. Coefficient of Determination Results

\begin{tabular}{|c|c|l|}
\hline Variable & $R$-Square & Description \\
\hline $\begin{array}{c}\text { Brand Trust } \\
\mathrm{BT}=\mathrm{f}(\mathrm{BC}, \mathrm{BE}, \mathrm{BI})\end{array}$ & 0.538 & Currently \\
\hline $\begin{array}{c}\text { Brand Image } \\
\mathrm{BI}=\mathrm{f}(\mathrm{BC}, \mathrm{BE})\end{array}$ & 0.588 & Currently \\
\hline $\begin{array}{c}\text { Brand Loyalty } \\
\mathrm{BL}=\mathrm{f}(\mathrm{BT}, \mathrm{BE}, \mathrm{BI})\end{array}$ & 0.586 & Currently \\
\hline
\end{tabular}

\section{Path Coefficient Test}

According to Sholiha (2015), bootstrapping is a tool used to minimize the reliability of the relationship with the error of using the normal distribution and its users.

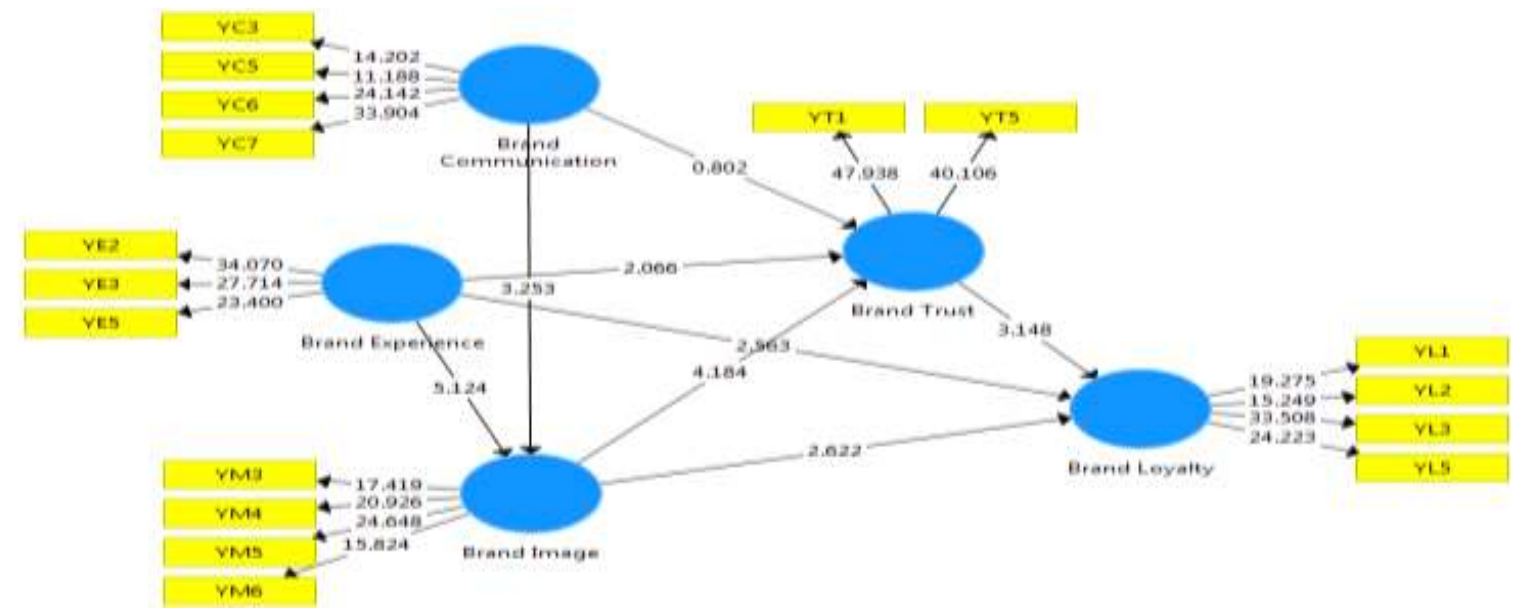

Figure 2. Bootstrapping Results

It can be seen that the variable has a path coefficient with a positive number, which indicates that the influence between variables is unidirectional.

\section{Hypothesis Test (t-statistical test)}

Table 5. Hypothesis Test Results

\begin{tabular}{|l|c|c|c|c|c|}
\hline & Original Sample (O) & Sample Mean $(\mathrm{M})$ & Standard Deviation (STDEV) & T Statistics (|O/STDEV) & P Values \\
\hline Brand Communication -> Brand Image & 0.323 & 0.336 & 0.099 & 3.253 & 0.001 \\
\hline Brand Communication -> Brand Trust & 0.063 & 0.071 & 0.078 & 0.802 & 0.423 \\
\hline Brand Experience -> Brand Image & 0.536 & 0.526 & 0.105 & 5.124 & 0.000 \\
\hline Brand Experience -> Brand Loyalty & 0.284 & 0.272 & 0.111 & 2.563 & 0.011 \\
\hline Brand Experience -> Brand Trust & 0.250 & 0.256 & 0.121 & 2.066 & 0.039 \\
\hline Brand Image -> Brand Loyalty & 0.294 & 0.299 & 0.112 & 2.622 & 0.009 \\
\hline Brand Image -> Brand Trust & 0.488 & 0.480 & 0.117 & 4.184 & 0.000 \\
\hline Brand Trust -> Brand Loyalty & 0.283 & 0.296 & 0.090 & 3.148 & 0.002 \\
\hline
\end{tabular}


Hypothesis Test Results 1: Brand communication has a positive and significant influence on brand image, meaning that $\mathrm{H} 1$ is accepted.

Hypothesis Test Results 2: Brand communication has a positive and insignificant effect on brand trust, meaning that $\mathrm{H} 2$ is rejected.

Hypothesis Test Results 3: Brand experience has a positive and significant influence on brand image, meaning that $\mathrm{H} 3$ is accepted.

Hypothesis Test Results 4: Brand experience has a positive and significant influence on brand trust, meaning that $\mathrm{H} 4$ is accepted.

Hypothesis Test Results 5: Brand experience has a positive and significant influence on brand loyalty, meaning that $\mathrm{H} 5$ is accepted.

Hypothesis Test Results 6: Brand image has a positive and significant influence on brand trust, meaning that $\mathrm{H} 6$ is accepted.

Hypothesis Test Results 7: Brand image has a positive and significant effect on brand loyalty, meaning that $\mathrm{H} 7$ is accepted.

Hypothesis Test Results 8: Brand trust has a positive and significant effect on brand loyalty, meaning that $\mathrm{H} 8$ is accepted.

Hypothesis Test Results 9: Brand trust cannot mediate brand communication on brand loyalty, meaning that it is rejected. Brand trust can mediate brand experience and brand image on brand loyalty, meaning that it is accepted.

\subsection{Discussion}

Based on the results of the $\mathrm{H} 1$ test, brand communication is able to have a positive influence on the brand image of Yamaha motorcycles in West Jakarta. Then the hypothesis H1 is supported. This is in line with previous research (Chinomona, 2016; Toha, 2016). The results of the $\mathrm{H} 2$ test, brand communication is not significant to Yamaha motorcycle brand trust in West Jakarta. So it can be concluded that hypothesis H2 is rejected. This is not in line with previous research which has found a positive relationship between brand communication and brand trust (Ngatno, 2017; Zehir et al., 2011). The results of the H3 brand experience test are able to have a positive influence on the brand image of Yamaha motorcycle products in West Jakarta. So it can be concluded that the hypothesis H3 is supported. This is in line with previous research (Rahmat \& Marso, 2020). The results of the $\mathrm{H} 4$ brand experience test were able to have a positive influence on the brand trust of Yamaha motorcycles in West Jakarta. So it can be concluded that the hypothesis H4 is supported. This is in line with previous research (Huang, 2017; Ha, H. Y., \& Perks, H., 2005). The results of the H5 test state that brand experience can have a positive influence on Yamaha motorcycle brand loyalty in West Jakarta. So it can be concluded that H5 is supported. This is in line with previous research (Rahmat \& Marso, 2020; Pandean \& Budiono, 2021). The results of the $\mathrm{H} 6$ brand image test are able to give a positive influence on the brand trust of Yamaha motorcycles in West Jakarta. So it can be concluded that the hypothesis H6 is supported. This is in line with previous research (Chinomona, 2016; Toha, 2016; Fianto, 2014). The results of the H7 brand image test are able to provide a positive influence on brand loyalty for Yamaha motorcycles in West Jakarta. So it can be concluded that the hypothesis $\mathrm{H} 7$ is supported. This is in line with previous research (Rahmat \& Marso, 2020; Pandean \& Budiono, 2021). The results of hypothesis testing H8 state that brand trust affects Yamaha motorcycle brand loyalty in West Jakarta. So it can be concluded that the hypothesis $\mathrm{H} 8$ is supported. This is in line with previous research (Chinomona, 2016; Zehir, C., ahin, A., Kitapçı, H., \& zşahin, M., 2011; Pandean \& Budiono, 2021). 


\section{Conclusion}

1. Brand communication has a positive and significant influence on the brand image of Yamaha motorcycle products in West Jakarta.

2. Brand communication has a positive and insignificant effect on brand trust for Yamaha motorcycle products in West Jakarta.

3. Brand experience has a positive and significant influence on the brand image of Yamaha motorcycle products in West Jakarta.

4. Brand experience has a positive and significant impact on brand trust for Yamaha motorcycle products in West Jakarta.

5. Brand experience does not have a positive and significant effect on brand loyalty for Yamaha motorcycle products in West Jakarta.

6. Brand image has a positive and significant impact on brand trust for Yamaha motorcycle products in West Jakarta.

7. Brand image has a positive and significant influence on brand loyalty for Yamaha motorcycle products in West Jakarta.

8. Brand trust has a positive and significant impact on brand loyalty for Yamaha motorcycle products in West Jakarta.

9. Brand trust cannot mediate brand communication on brand loyalty of Yamaha motorcycle products in West Jakarta. Brand trust can mediate brand experience and brand image on brand loyalty of Yamaha motorcycle products in West Jakarta.

\section{References}

Arenggoasih, W. (2016). Pengaruh Brand Communication, Service Quality Dan Brand Personality Anggota Dewan Terpilih Melalui Brand Trust Terhadap Brand Loyalty Pemilih (Studi Partai Politik Gerindra). Interaksi: Jurnal Ilmu Komunikasi, 5(2), 123-135.

Asmuni, et al. (2020). Implementation of the principle of sale and purchase transactions through MLM in Brand Branch (BC) PT. Herba Penawar Alwahida Indonesia (HPAI) Tanjungbalai. Budapest International Research and Critics Institute-Journal (BIRCI-Journal) Volume 3, No. 4, Page: 3376-3385

Atulkar, S. (2020). Brand trust and brand loyalty in mall shoppers. Marketing Intelligence \& Planning.

Bernarto, I., Berlianto, M. P., Meilani, Y. F., Masman, R. R., \& Suryawan, I. N. (2020). The influence of brand awareness, brand image, and brand trust on brand loyalty. Jurnal Manajemen, 24(3), 412426.https://doi.org/http://dx.doi.org/10.24912/jm.v24i3.676

Bilgin, Y. (2018). The effect of social media marketing activities on brand awareness, brand image and brand loyalty. Business \& Management Studies: An International Journal, 6(1), 128-148. https://doi.org/http://dx.doi.org/10.15295/bmij.v6i1.229

Chinomona, R. (2016). Brand communication, brand image and brand trust as antecedents of brand loyalty in Gauteng Province of South Africa. African Journal of Economic and Management Studies, 7(1), 124-139. https://doi.org/doi:10.1108/ajems-03-20130031

Ebrahim, R. S. (2020). The role of trust in understanding the impact of social media marketing on brand equity and brand loyalty. Journal of Relationship Marketing, 19(4), 287-308. 
Hussein, A. S. (2018). Effects of Brand Experience on Brand Loyalty inIndonesian Casual Dining Restaurant: Roles of Customer Satisfaction andBrand of Origin. Tourism and Hospitality Management, 24(1), 119-132. https://doi.org/https://doi.org/10.20867/thm.24.1.4

Kusuma, Y. S. (2014). Pengaruh brand experience terhadap brand loyalty melalui brand satisfaction dan brand trust Harley Davidson di Surabaya. Jurnal Strategi Pemasaran, 2(1), 1-11.

Marlizar, et al. (2020). The Role of Market Orientation and Creativity in Affecting the Marketing Performance of Market Traders in Aceh Market Banda Aceh City. Budapest International Research and Critics Institute-Journal (BIRCI-Journal).P. 1114-1127

Nuhadriel, Y., Japiana, M., \& Keni, K. (2021). Pentingnya Brand Communication, Brand Experience, Dan Brand Image Dalam Meningkatkan Brand Loyalty Pada Ritel Furnitur: Brand Trust Sebagai Variabel Mediasi. Jurnal Ilmiah Ekonomi Bisnis, 26(3), 264-277.

Pandean, A. V., \& Budiono, H. (2021). Brand Image Dan Brand Experience Untuk Memprediksi Brand Loyalty Mcdonald's Dengan Brand Trust Sebagai Variabel Mediasi. Jurnal Manajerial Dan Kewirausahaan, 3(1), 156-164.

Peredo Paredes, Mireya Lucía, and M. T. V. O. (2020). Online brand experience, brand image, brand trust y customer satisfaction en relación al e-brand engagement en canales digitales de e-fashion retail. [Universidad Peruana De Ciencias Aplicadas]. https://doi.org/https://repositorioacademico.upc.edu.pe/bitstream/handle/10757/6554 45/PeredoP_M.pdf?sequence $=3$

Pratiwi, D. M. (2015). The influence of brand image, brand trust and customer satisfaction on brand loyalty (Case of Samsung Smartphone). Jurnal Berkala Ilmiah Efisiensi, $15(5)$.

Rahmat, R., \& Marso, M. (2020). Hubungan brand experience, brand image, brand satisfaction, dan brand loyalty dalam pespektif four-stage loyalty model (studi terhadap mahasiswa pengguna smartphone Di TARAKAN). Jurnal Manajemen Pemasaran, 14(1), 17-24.

Rizan, Mohammad, Basrah Saidani, and Y. S. (2012). "Pengaruh Brand Image Dan Brand Trust Terhadap Brand Loyalty Teh Botol Sosro Survei Konsumen Teh Botol Sosro Di Food Court Itc Cempaka Mas, Jakarta Timur." JRMSI-Jurnal Riset Manajemen Sains Indonesia, 3.1, 1-17.

Romdonah, R., Fathoni, A., \& Haryono, A. T. (2015). Pengaruh Inovasi Produk, Harga dan Brand Image Terhadap Keputusan Pembelian Sepeda Motor Honda Beat (Studi Kasus pada Konsumen Dealer Honda Pratama Kurnia Kasih). Journal of Management, 1(1).

Romdonny, J., Rosmadi, M. L. N. (2019). Factors Affecting Customer Loyalty in Products. Budapest International Research and Critics Institute-Journal (BIRCI-Journal) Volume 2, No 1, Page: 337-343

Sasmita, J., \& Suki, N. M. (2015). Young consumers' insights on brand equity: Effects of brand association, brand loyalty, brand awareness, and brand image. International Journal of Retail \& Distribution Management.

Świtała, M., Gamrot, W., Reformat, B., \& Bilińska-Reformat, K. (2018). The influence of brand awareness and brand image on brand equity-an empirical study of logistics service providers. Journal of Economics \& Management, 33, 96-119.

Van der Westhuizen, L. M. (2018). Brand loyalty: exploring self-brand connection and brand experience. Journal of Product \& Brand Management. 
Veronica, V., \& Rodhiah, R. (2021). Pengaruh Privacy, Social Influence Terhadap Online Purchase Intention: Trust Sebagai Variabel Mediasi. Jurnal Muara Ilmu Ekonomi Dan Bisnis, 5(2), 235-246.

Winnie, K. (2020). Brand Experience Dan Perceived Quality Terhadap Brand Loyalty: Brand Trust Sebagai Variabel Mediasi. Jurnal Manajerial Dan Kewirausahaan, 2(2), 501-509.

Zehir, C., Sahin, A., Kitapçı, H., \& Öz,sahin, M. (2011). The effects of brand communication and service quality in building brand loyalty through brand trust; the empirical research on global brands. Procedia-Social and Behavioral Sciences, 24, 1218-1231. https://doi.org/https://doi.org/10.1016/j.sbspro.2011.09.142 